\title{
Population and mortality profile in the Islamic Republic of Iran, 2006-2035
}

Saeide Aghamohamadi, ${ }^{1}$ Kamran Hajinabi, ${ }^{2}$ Katayoun Jahangiri, ${ }^{3}$ Iravan Masoudi Asl ${ }^{4}$ and Reza Dehnavieh ${ }^{5}$

${ }^{1}$ Department of Health Services Administration, Science and Research Branch, Islamic Azad University, Tehran, Islamic Republic of Iran. ${ }^{2}$ Department of Health Services Administration, Science and Research Branch, Islamic Azad University, Tehran, Islamic Republic of Iran (Correspondence to: Kamran Hajinabi: kamran.hajinabi@gmail.com). ${ }^{3}$ Department of Health in Disasters and Emergencies, School of Health, Safety \& Environment (HSE), Shahid Beheshti University of Medical Sciences, Tehran, Islamic Republic of Iran. ${ }^{4}$ Islamic Parliament Research Center, Tehran, Islamic Republic of Iran. ${ }^{5}$ Department of Health Service Management. Institute for Future Studies in Health, Kerman, Islamic Republic of Iran.

\begin{abstract}
Background: The Islamic Republic of Iran has encountered demographic and epidemiological changes as a result of the transformation of health measures.
\end{abstract}

Aims: This study aimed to calculate the population and mortality in the Islamic Republic of Iran during the years 2006 to 2035 .

Methods: We carried out a cross-sectional analytical-descriptive account. We calculated the age and sex structure of the Iranian population using census data as well as mathematical methods. The crude and causal death rates were calculated and their 20 -year trend was predicted using the Lee-Carter model.

Results: In 2035, the age group 60 years and over will reach 17.6\% of the total population. Endocrine, nutritional and metabolic diseases will be the biggest causes of an increase in the rate of death in the general population. The largest decline in cause of death is for unintentional injuries.

Conclusions: Noncommunicable diseases will increase as the aging population grows. Identification of their primary causal and risk factors can, therefore, contribute to prevention and control.

Keywords: profile, prediction, population, cause of death, Iran

Citation: Aghamohamadi S; Hajinabi K; Jahangiri K; Masoudi Asl I; Dehnavieh R. Population and mortality profile in the Islamic Republic of Iran, 2006-2035. East Mediterr Health J. 2018;24(5):469-476. https://doi.org/10.26719/2018.24.5.469

Received: 18/12/16; accepted: 13/04/17

Copyright @ World Health Organization (WHO) 2018. Some rights reserved. This work is available under the CC BY-NC-SA 3.0 IGO license (https:// creativecommons.org/licenses/by-nc-sa/3.o/igo).

\section{Introduction}

One of the most important variables to be calculated regarding social planning is the size and characteristics of the population and its transformation process in the past, present and future (1). After the Second World War, many countries and international organizations became concerned about the increasing population. Their concern was not just about the population explosion, but also the continuation of the process of demographic change and the phenomenon of demographic transition. Other demographic challenges began to stand out, such that age transition, age structure, demographic window, population aging and other factors began to enter the literature. The population explosion has drawn the attention of planners and experts, while the implementation of birth control and renewing generation policies had an unprecedented effect on the changing age structure of the population (2).

Today, this change can be seen in the structure and composition of the population of the Islamic Republic of Iran and has had a number of negative consequences for the economic, social and political system of the country. So, adverse changes, even natural changes, in the structure of the population (age structure) and the lack of planning to manage these developments is seen as a serious threat, and in many cases causes irreparable damage to public safety (3).

The country is in the third epidemiological transition (4), where it is assumed the rate of death from infectious diseases decreases, while the rate of death from chronic diseases increases (5). Recognizing these changes allows for providing different manifestations of public health in the present and future and, thus, involves managers in social development planning, the training of health care workers, shaping the structure of health care service provision and, eventually, improving the community (4).

Considering the importance of recognizing the health transition transformation, this study deals with investigating and predicting the age and sex structure of the population, as well as the causes of death in the Islamic Republic of Iran from 2006 to 2035.

\section{Methods}

\section{Data collection and analysis}

This was a cross-sectional descriptive-analytic study conducted in 2 phases. In the first phase, the age and sex structure of the population was predicted in 3 steps. In the first step, using data from the General Population and Housing Census in 2006 and 2011, the population data were extracted (6-8). In the second step, a prediction 
of the population of the country was estimated up to the year 2035 with 4 fertility assumptions published by the Statistical Center of Iran (9) and using a mathematical method. The mathematical method is one of the ways of predicting population growth, and is expressed through the following relationship (10):

$$
P_{\mathrm{t}}+n=P_{\mathrm{t}}(1+\mathrm{r})^{\mathrm{n}}
$$

Where, $P_{t}+n$ is the population in the second census, $P_{t}$ is the population at the first census, $\mathrm{n}$ is the gap between the 2 censuses, and $r$ is the annual growth rate of the population, which is the basis for the calculations (in this study, to estimate the population in 2016, 2021, 2026, 2031 and 2035 as $P_{t}+n, P_{t}$ was considered, respectively, the population in 2011, 2016, 2021, 2026 and 2031).

In the third step, given the calculated populations for the whole country, and by using the United Nations population prediction information for the next 150 years (11), the population was estimated in 5-year age and sex groups.

In the second phase, the value of the general groups for cause of death in the country was assessed, calculated and predicted during the indicated years. In this phase, the study population comprised total deaths registered in the system and classification of cause of death by the Ministry of Health and Medical Education for the years 2006-2015, grouped by cause of death, sex and age. These data were collected from various sources, including hospitals, clinics, surgeries, legal medicine organizations, health centres, health care centres and cemeteries during the investigation. Data collection instruments included death certificates, burial permits and information forms.

It should be noted that this study is not based on individual information and medical intervention and so there was no need for ethical approval, however, formal permission from the Ministry of Health and Medical Education, number D308/22604, was issued to use of mortality data.

After data collection, cause of death was determined, coded and recorded based on the International Statistical Classification of Diseases (12-14) and numbers of deaths in terms of cause of death, sex and age group were calculated. The death rate was computed per 100000 population. Population estimates between 2 censuses were employed for the years 2007-2010 and 2012-2015. For the years 2006 and 2011, the census information for each year was used $(7,8)$.

\section{Predicting crude rates and the main group rate doe cause of death}

After calculating the crude and causal rates of death in 5-year age groups during the study period, the 20-year trend was predicted using the Lee-Carter model (15).

The structure of the proposed Lee-Carter model is presented as follows:

$$
\begin{aligned}
& \operatorname{Ln}\left(m_{x, t}\right)=a_{x}+b_{x} k_{t}+\varepsilon_{x, t} \\
& \text { Where: }
\end{aligned}
$$

- $\operatorname{Ln}\left(\mathrm{m}_{\mathrm{x}, \mathrm{t}}\right)$ indicates the natural logarithm of death (mortality) rates observed for age $\mathrm{x}$ and in year t;

- $\mathrm{a}_{\mathrm{x}}, \mathrm{b}_{\mathrm{x}} \mathrm{k}_{\mathrm{t}}$ and $\varepsilon_{\mathrm{x}, \mathrm{t}}$ are age and time dependent parameters:

- $a_{x}$ indicate the average time logarithm of death rates at age $\mathrm{x}$;

- $\mathrm{k}_{\mathrm{t}}$ is the mortality index in year $\mathrm{t}$, which indicates the main trend in the natural logarithm of mortality rates for all ages over time;

- $b_{x}$ shows the rate of change in the mortality rate logarithm at age $\mathrm{x}$ to (per) changes in the mortality index over time;

- component $\varepsilon_{\mathrm{x}, \mathrm{t}}$ is equal to the component error at age $\mathrm{x}$ and time (15).

The Lee-Carter model, as a generalization method, is a combination of a rich demographic model (without the least parameters) and time series methods (16). In short, this method predicts death by age and period duration for a single population (15). One of the strengths of the Lee-Carter method, as well as other generalizing methods is its use in conditions where there is a linear trend of death rates in different age groups (17). However, due the existence of the linear trend in death rates, and introducing the Lee-Carter method as a leading method for the prediction of mortality (16), this method was utilized to predict crude death rate and cause of death groups in this study.

It should be noted that, in this model, the International Classification of Diseases was used to predict the trend for cause of death (12-14). Of the total of 21 main disease groups in this classification, the diseases that cannot be considered as the underlying cause of death (e.g. diseases of the eye and adnexa, diseases of the ear and mastoid process and factors influencing health status and contact with health services) were excluded from the study because, according to the International Classification of Diseases, the underlying cause has been defined as "(a) the disease or injury which initiated the train of morbid events leading directly to death, or (b) circumstances of the accident or violence which produced the fatal injury" (13) and these diseases are not included in this definition. Also disease groups such as diseases of the skin and subcutaneous tissue, diseases of the musculoskeletal system and connective tissue; pregnancy, childbirth and the puerperium; and conditions originating in the perinatal period with negligible or zero value in age and sex groups were excluded from the study because their trend was not predictable by this model. Ultimately, a forecast for 13 major groups for cause of death was conducted.

\section{Data analysis tools:}

The demography package (18.1) of the Lee-Carter model in the $R$ software, version 3.3.1, was utilized to predict mortality rates in the main groups for cause of death.

\section{Results}

In the census year 2006, the population of the Islamic Republic of Iran was 70495782 (34 629420 females and 

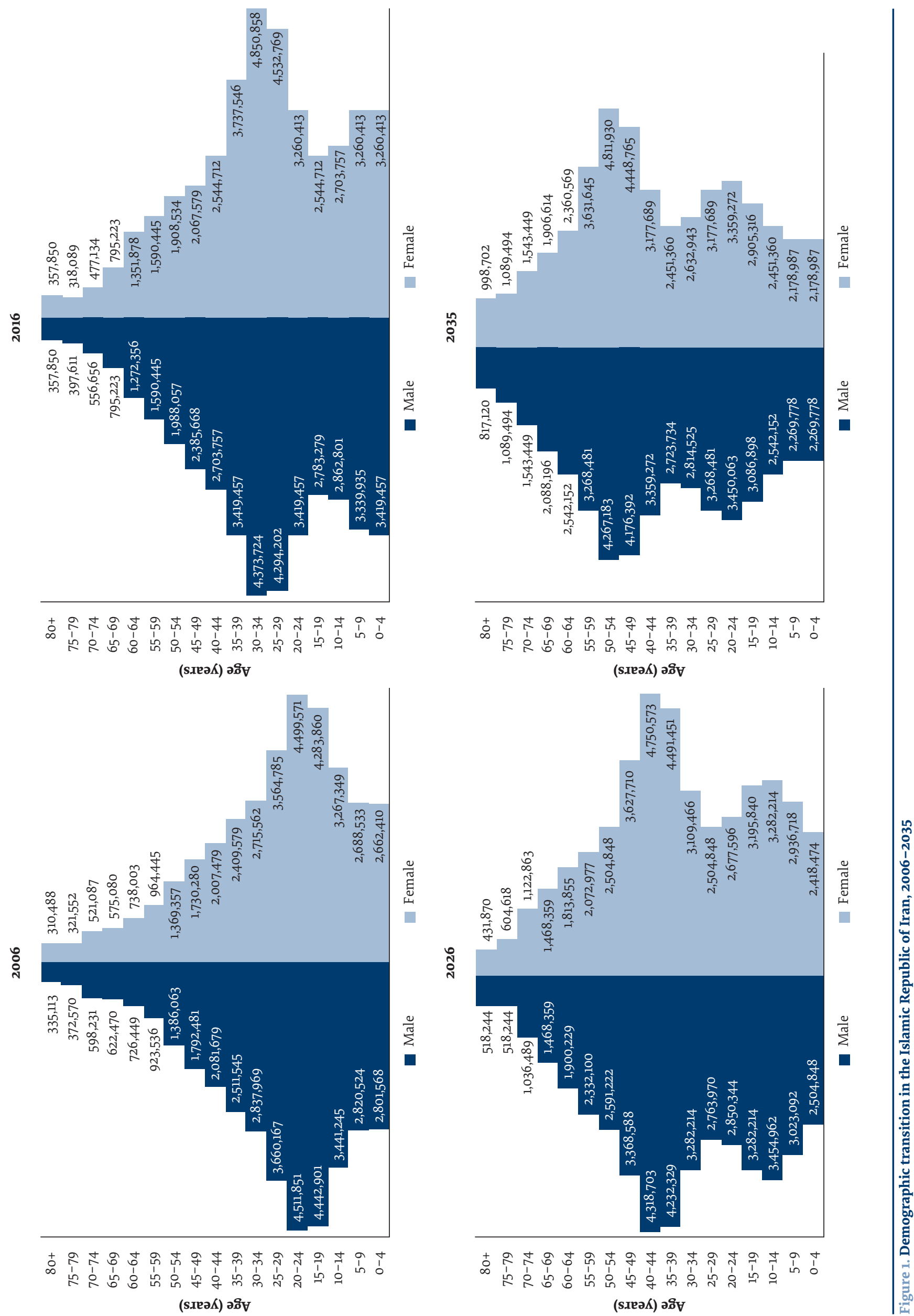


\begin{tabular}{|c|c|c|c|c|c|c|c|c|c|c|c|c|}
\hline \multirow[t]{2}{*}{ Year } & \multicolumn{3}{|c|}{ Rate of decline (1.3) } & \multicolumn{3}{|c|}{ Stabilization rate (1.8) } & \multicolumn{3}{|c|}{$\begin{array}{l}\text { Increase rate up to } \\
\text { replacement level (2.1) }\end{array}$} & \multicolumn{3}{|c|}{$\begin{array}{l}\text { Increase rate above } \\
\text { replacement level (2.5) }\end{array}$} \\
\hline & Female & Male & Total & Female & Male & Total & Female & Male & Total & Female & Male & Total \\
\hline 2016 & 39.48 & 39.88 & 79.37 & 39.60 & 39.92 & 79.53 & 39.61 & 40.04 & 79.64 & 39.66 & 40.06 & 79.72 \\
\hline 2021 & 41.36 & 41.69 & 83.04 & 41.52 & 41.85 & 83.38 & 41.63 & 41.96 & 83.58 & 41.77 & 42.10 & 83.87 \\
\hline 2026 & 42.806 & 43.23 & 86.03 & 43.01 & 43.45 & 86.47 & 43.19 & 43.62 & 86.80 & 43.38 & 43.81 & 87.20 \\
\hline 2031 & 43.930 & 44.37 & 88.30 & 44.21 & 44.65 & 88.87 & 44.43 & 44.88 & 89.31 & 44.67 & 45.12 & 89.80 \\
\hline 2035 & 44.92 & 45.193 & 90.12 & 45.30 & 45.58 & 90.89 & 45.60 & 45.88 & 91.47 & 45.92 & 46.19 & 92.11 \\
\hline
\end{tabular}

35866362 males). In the 2011 census, the population reached 75103347 (37226196 females and 37877151 males). The population by the year 2035 was estimated based on the 4 fertility assumptions (Table 1).

In 2006 , the population comprised the following age groups: $\leq 5$ years $7.75 \%$, 5-14 years $17.33 \%$, 15-49 years $61.06 \%$, 50-69 years $10.36 \%$, and $\geq 70$ years $3.49 \%$. We estimated that in 2035 the population will be: 5 years and under $4.9 \%$, 5-14 years $10.4 \%, 15-49$ years $49.6 \%$, 50-69 years $27.4 \%$, and $\geq 70$ years $7.8 \%$. The process of change in the age and sex structure of the population during 20062035 is shown in age pyramids in Figure 1.

According to the data available, the crude death rate in 2006 in the total population is calculated at 4.36 per 1000 population (female 3.65 , male 5.04). It is estimated that, in 2035 , the crude death rate for the whole population will reach 4.05 per 1000 population (female 3.74, male 4.47). The trend for crude death rates is shown in Figure 2.

In 2006, the top 3 causes of death in females were diseases of the circulatory system, neoplasms and unintentional injuries (193.63, 42.38 and 30.49 per 100000 population respectively). Mental and behavioural disorders, infectious and parasitic diseases and diseases of the blood and blood-forming organs showed the lowest rates for cause of death $(4.67,3.41$ and 1.75 per 100000 population respectively). However, it is predicted that in 2035 the rate for endocrine, nutritional and metabolic diseases will be 202.97 , diseases of the circulatory system will be 132.66, and neoplasms will be 113.68 per 100000 population, and these will be the main groups among the major causes of death in females. Diseases of the blood and blood-forming organs, mental and behaviour disorders and intentional injuries (2.70, 0.80 and 0.51 per 100000 population respectively) will have the lowest rates for cause of death (Table 2).

Additionally, in 2006 diseases of the circulatory system, unintentional injuries and neoplasms (211.52, 99.03 and 62.84 per 100000 population respectively) were the 3 major causes of death in males. Diseases of the nervous system, infectious and parasitic diseases, and diseases of the blood and blood-forming organs $(6.36,5.64$ and 1.9 per 100000 population respectively) showed the lowest rates for cause of death. It is predicted that in 2035 diseases of the circulatory system, endocrine, nutritional and metabolic diseases, and neoplasms (211.41, 188.99 and 134.84 per 100000 population respectively) will be the major groups among causes of death for males. Diseases of the blood and blood-forming organs, intentional injuries, and mental and behavioural disorders (5.83, 3.42 and 0.52 per 100000 population respectively) will show the lowest rates for cause of death (Table 3).

\section{Discussion}

In the 2oth century, improving health, decreasing number of deaths, increasing life expectancy and declining fertility have caused a rapid unprecedented demographic transition (18). According to the United Nations, in recent years the growth rate of the world's elderly population, $19 \%$, is considerably higher than the growth rate of the total world population, $12 \%$. Predictions show that in the period 2025-2030, the elderly population will grow 35 times faster than the total population (19). The results of the biological study of the population also show that the demographic characteristics of today's world are heading towards further aging. Globally, the elderly population is rapidly increasing, with the number of people aged 60 years and above having doubled over the last 3 decades. It is expected that, from 2010 to 2050 , their numbers will have risen from 795 million to 2 billion (20). Based on the results of our study, from 2006 to 2035 the growth of the elderly population in the Islamic Republic of Iran will increase in a similar fashion: in 2006 the population aged over 60 years made up $7.3 \%$ of the total population; it is estimated that in 2016 it will reach $8.4 \%$, in $202612.6 \%$ and in 2035 it is expected to reach $17.6 \%$.

It is predicted that, in 2035, the Islamic Republic of Iran will be beyond the epidemiological transition. During this time, chronic diseases will emerge, most of which will be diseases of aging (21). The death rate from the endocrine, nutritional and metabolic diseases shows a substantial increasing trend. It is predicted that from 10.19 per 100000 population in 2006, the rate will reach 78.78 per 100000 population in 2026 and 197.71 per 100000 population in 2035. In this regard, the prediction for global death rates and burden of disease shows that the more advanced a country becomes, with higher incomes, the more noncontagious diseases will comprise the dominant sector for cause of death and burden of disease (22). It is predicted that diabetes will be the fourth leading cause of death in developed countries, the sixth in middle-income countries and the ninth in developing countries by $2030(23,24)$. According to the World Health Organization (WHO), diabetes will be the fifth leading cause of death worldwide by 2030 with a 


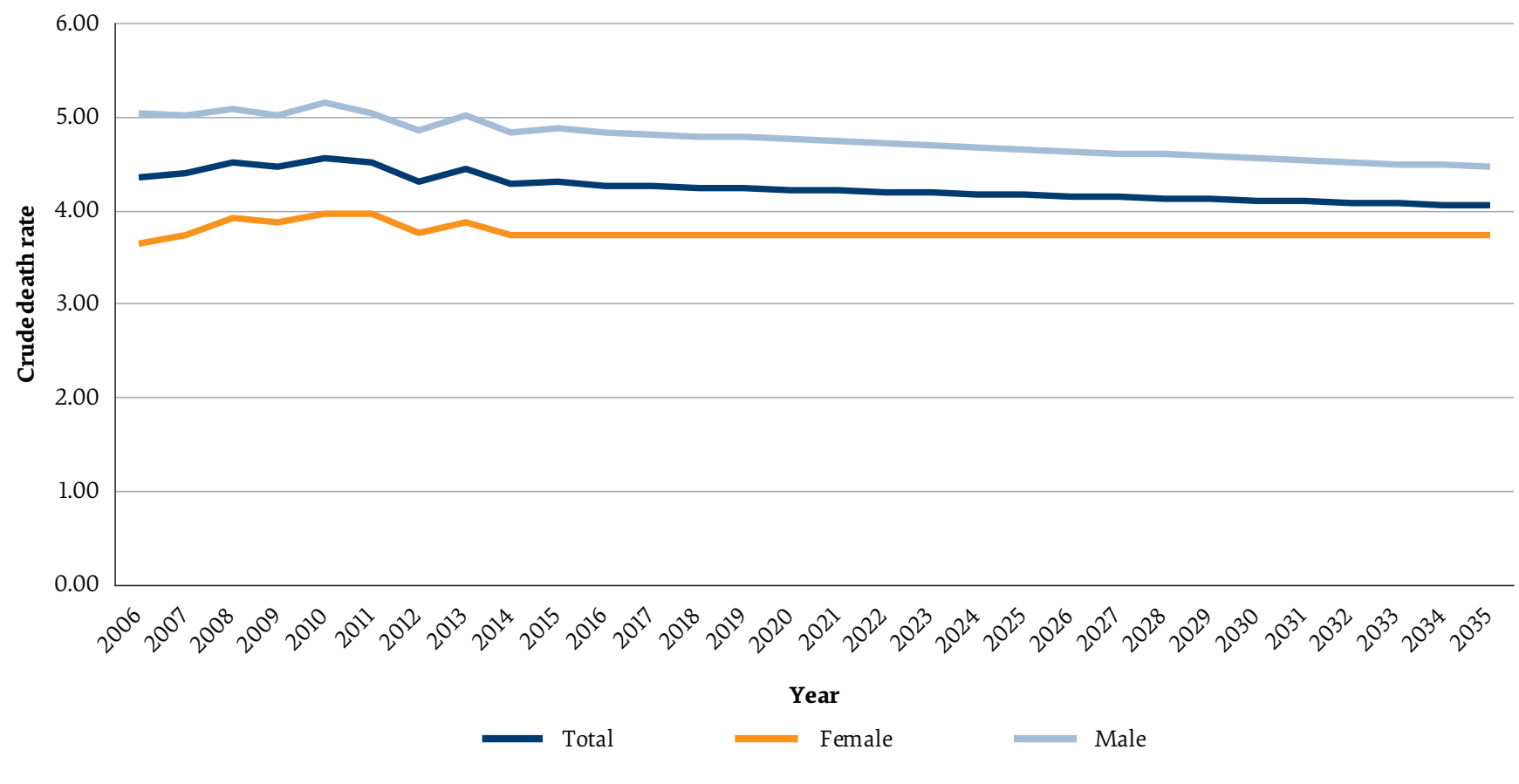

Figure 2. The trend of crude death rate from 2006 to 2035 (per 1000 population) according to sex

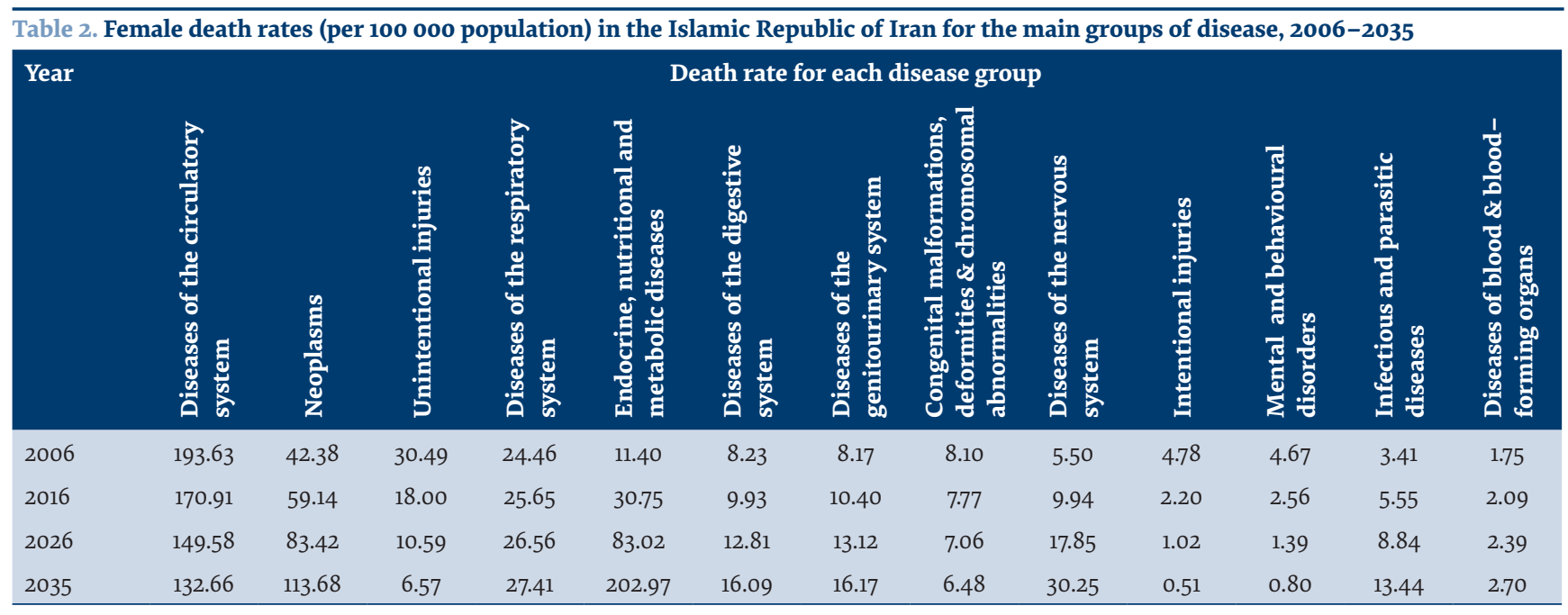

Table 3. Male death rates (per 100 ooo population) in the Islamic Republic of Iran for the main groups of disease, 2006-2035

\begin{tabular}{|c|c|c|c|c|c|c|c|c|c|c|c|c|c|}
\hline \multirow[t]{2}{*}{ Year } & \multicolumn{13}{|c|}{ Death rate for each disease group } \\
\hline & 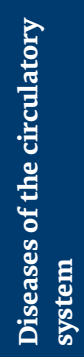 & 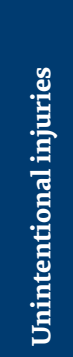 & 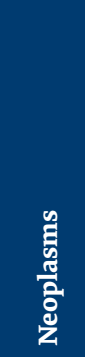 & 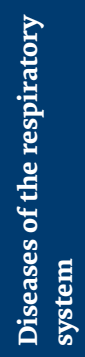 & 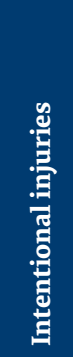 & 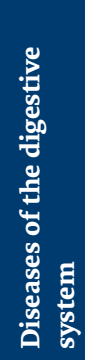 & 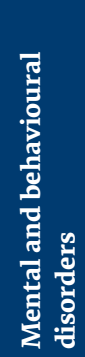 & 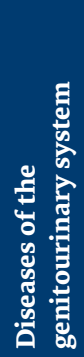 & 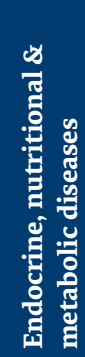 & 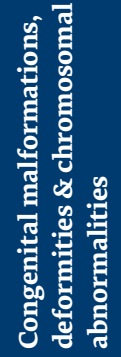 & 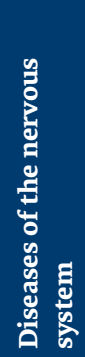 & 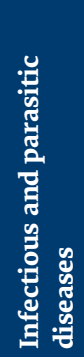 & 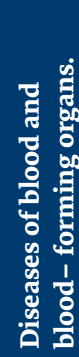 \\
\hline 2006 & 211.52 & 99.03 & 62.84 & 31.28 & 12.62 & 11.45 & 10.61 & 10.31 & 9.21 & 8.97 & 6.36 & 5.64 & 1.90 \\
\hline 2016 & 211.68 & 54.96 & 81.58 & 34.81 & 8.09 & 13.02 & 3.78 & 14.04 & 26.10 & 8.72 & 11.62 & 8.72 & 2.81 \\
\hline 2026 & 211.54 & 30.37 & 106.28 & 38.79 & 5.14 & 14.76 & 1.33 & 19.40 & 73.99 & 7.97 & 21.14 & 13.29 & 4.13 \\
\hline 2035 & 211.41 & 17.81 & 134.84 & 42.76 & 3.42 & 16.53 & 0.52 & 25.95 & 188.99 & 7.35 & 36.22 & 19.42 & 5.83 \\
\hline
\end{tabular}


rate of 30 per 100000 population (25) and comprise $1.4 \%$ of cause of death for females and about 3.0\% for males. In the Eastern Mediterranean Region, diabetes in females will account for $3.1 \%$ of deaths and males will account for $2.5 \%$ of deaths in 2015 . Based on the registration system for data and classification of cause of death used in this study, in 2015 diabetes accounted for $5.2 \%$ of deaths in the total population, $6.6 \%$ females and $4.11 \%$ males. This indicates a higher incidence of this disease in the Region, and it is expected that in the future the rate of diabetes in our country will exceed that of the overall rate for the countries of the Region.

Our findings also show that, with the aging population, diseases of the circulatory system will be the main cause of death in males in the Islamic Republic of Iran in 2035, and the second leading cause of death in females. According to WHO, diseases of the circulatory system, the leading cause of death in the world, have a high prevalence in old age, i.e. people aged $70+$ years; in 2030 , ischemic heart disease will be the leading cause of death in the world, and will constitute $33.4 \%$ of cause death for females and 30.6\% for men in the Eastern Mediterranean Region (25). A study carried out between 2010 and 2040 on the effect of an increase in the aging population on cardiovascular disease in the United States of America predicted that the rate of death due to coronary artery disease is strongly influenced by an aging population with a $56 \%$ increase (26).

Neoplasms are another major cause of death in the Islamic Republic of Iran. In general, cancers are one of the major problems in different areas of the world (27). According to our findings, it will be the third leading cause of death in the Islamic Republic of Iran in 2035. Also, according to cancer statistics in 2013, about $60 \%$ of the total cancers are seen in people aged $65+$ years
(28). The prevalence of cancers in different areas of the world is on the rise (25). An increase in cancer ratio by 2030 compared with 2008 has been estimated at $82 \%$ for low-income countries, $70 \%$ for average-low-income countries, $58 \%$ for countries with above average income and $40 \%$ for high-income countries.

In the Islamic Republic of Iran, the deaths from unintentional and intentional injuries have reduced considerably in both men and women and, according to our findings, it is predicted that unintentional injuries in 2035 compared to 2006 will be reduced by a rate of 24 in men and by 88 in women per 100000 population. Since the major proportion of unintentional injuries is related to traffic accidents, various reports, including mortality profile reports in 30 provinces (29) and reports of the Legal Medicine Organization of Iran (30), show a decreasing trend in these events and these numbers are expected to decline significantly.

Noncommunicable diseases account for more than $53 \%$ of the total burden of disease worldwide (4). It is expected that, by 2020 , they will be responsible for $60 \%$ of the total burden of disease and $73 \%$ of all deaths, $80 \%$ of which occur in developing countries. In the Islamic Republic of Iran, noncommunicable diseases account for more than $76 \%$ of the total burden of disease (4).

In the Islamic Republic of Iran the rise in the aging populations is one of the fastest in the world. An aging population is not important in itself, but its consequences and effects on socioeconomic and health care aspects doubles its importance. Increasing age will lead to a decline in health and a rise in chronic diseases, and will increase the burden of disease. The basis for prevention is to identify the primary risk factors, especially among the elderly population.

\section{Acknowledgements}

The authors wish to thank Dr Ardeshir Khosravi and Dr Elahe Kazemi of the Information and Statistical System Group in the Ministry of Health and Medical Education Network system, who cooperated on this study.

Funding: None.

Competing interests: None declared.

\section{Profil démographique et de la mortalité en République islamique d'Iran entre 2006 et 2035}

\section{Résumé}

Contexte : La République islamique d'Iran connaît des changements démographiques et épidémiologiques qui découlent d'une modification des mesures sanitaires.

Objectifs : La présente étude avait pour objectif d'estimer la population et la mortalité en République islamique d'Iran entre 2006 et 2035.

Méthodes: Il s'agissait d'un compte-rendu analytique et descriptif transversal. Nous avons calculé la structure par âge et par sexe de la population iranienne en utilisant les données de recensement et à l'aide de méthodes mathématiques. Le taux brut de mortalité et les taux de mortalité par cause ont été calculés et leur tendance sur 20 ans a été prédite à selon le modèle de Lee-Carter. 
Résultats : En 2035, le groupe d'âge des 60 ans et plus comptera pour $17,6 \%$ de la population totale. Les maladies endocriniennes, nutritionnelles et métaboliques seront les causes principales à l'origine d'une augmentation du taux de décès dans la population générale, et la baisse de décès la plus importante concernera les traumatismes non intentionnels.

Conclusion: Les maladies non transmissibles connaîtront une augmentation dans la population vieillissante dont le nombre croît en République islamique d'Iran. L'identification de leurs principaux facteurs de risque et causes peut donc contribuer à la prévention et la maîtrise de ces maladies.

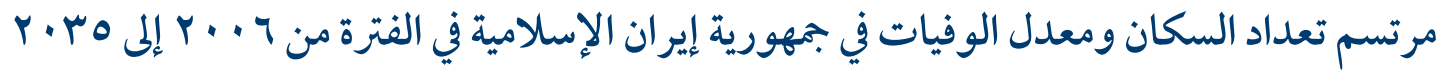

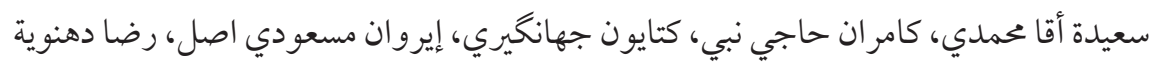

$$
\begin{aligned}
& \text { الخلاصة } \\
& \text { الخلفية: تشهل جمهورية إيران الإسلامية في الوقت الحالي تغيرات سكانية ووبائية ناجمة عن تغير التدابير الصحية. }
\end{aligned}
$$

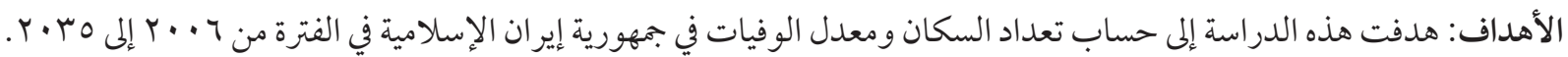

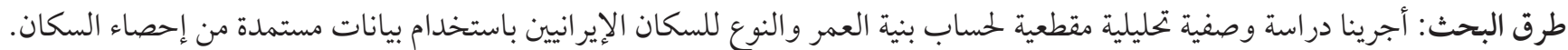

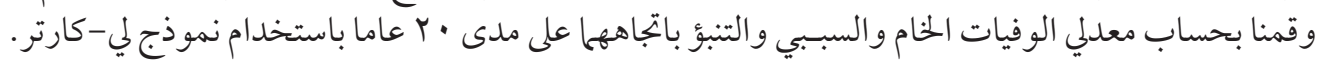

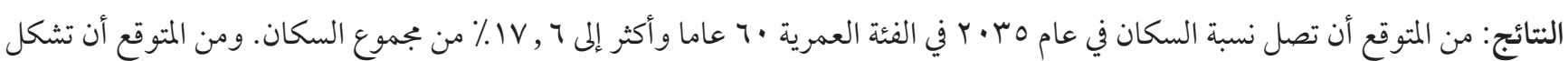

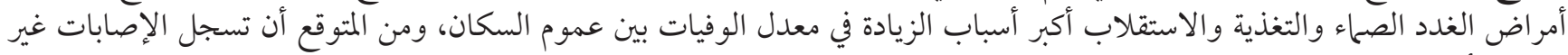

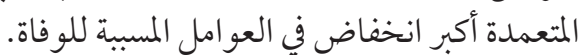

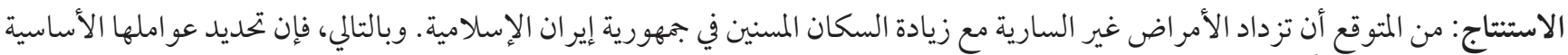

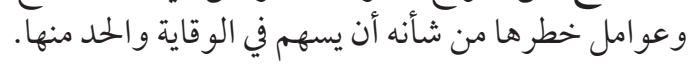

\section{References}

1. Kinsella KG, Phillips DR. Global aging: the challenge of success. Population Bull. 2005;60(1):5-43.

2. Saraei H. The crowd valve Iran. Planning, Social Welfare and Development J. 2010;1(1):33-45 [in Farsi].

3. Khosravi Vashmgir H. Pathological changes in the Iran population structure by economic security approach. Tehran: Research Institute, Fiscal Strategies; 2009 [in Farsi].

4. Naghavi M. Health transition in Iran. Iran J Epidemiol. 2006;2(2):45-57 ()http://irje.tums.ac.ir/article-1-185-fa.pdf, accessed 8 March 2018 [in Farsi].

5. Hatami H. Comprehensive public health. Tehran: Ministry of Health and Medical Education; 2012 [in Farsi].

6. General census of population and housing. Tehran: Statistical Center of Iran; 1996 (https://amar.sci.org.ir/PlanList.aspx, accessed 8 September 2015) [in Farsi].

7. General census of population and housing. Tehran: Statistical Center of Iran; 2006 (https://www.amar.org.ir/Portals/o/ sarshomarigo/n_sarshomarigo_2.pdf, accessed 15 September 2015) [in Farsi].

8. General census of population and housing Tehran: Statistical Center of Iran; 2011 (https://www.amar.org.ir/Portals/o/ sarshomarigo/n_sarshomarigo_2.pdf, accessed 23 September 2015) [in Farsi].

9. Growth forecast for the country's population in the five-year period until 1430 solar year. Tehran: Statistical Center of Iran; 2012 (http://www.amar.org.ir/Portals/o/SlideShow_Photos/files/baravord_1420_r2.xlsx, accessed 10 Feb 2016) [in Farsi].

10. Kazemi Pour Sh. Basics of demography. Tehran: Center for Population Studies and Research of Asia and Oceania; 2004 [in Farsi].

11. World population prospects. United Nations, Department of Economic and Social Affairs, Population Division 2015 (https://www. populationpyramid.net/iran-islamic-republic-of/2017/, accessed 5 Nov 2016).

12. International statistical classification of diseases \& related health problems. Volume 1. 10th rev ed. Geneva: World Health Organization; 1992.

13. International statistical classification of diseases \& related health problems. Volume 2. 10th rev. ed. Geneva: World Health Organization; 1992.

14. International Statistical Classification of Diseases \& Related Health Problems. Volume 3. 10th rev. ed. Geneva: World Health Organization; 1992.

15. Lee RD, Carter LR. Modelling and forecasting U.S. mortality. American Statistical Association J. 1992;87(419):659-71.

16. Deaton A, Pakson CP. Mortality, income, and income inequality over time in the Britain and the United States. Cambridge, Massachusetts: National Bureau of Economic Research; 2004 (Technical Report 8534). 
17. Booth H, Hyndman RJ, Tickle L, De Jong P. Lee-Carter mortality forecasting: a multi-country comparison of variants and extensions. Demographic Res. 2006;15(9):289-310.

18. Aging and health: a shift in the paradigm. Washington, DC: Pan American Health Organization; 1998 (CE12213).

19. World population aging 1950-2050. World Health Organization; 2002.

20. Christense K. Human biodemography: some challenges and possibilities for aging research. Demographic Res. 2008;19(43):157586.

21. Pour Reza A. Khabiri Nemati R. Economics of health and ageing. Iran J Ageing. 2206;1(2):80-8 [in Farsi].

22. Mathers CD, Loncar D. Projections of global mortality and burden of disease from 2002 to 2030. PLoS Med. 2006 Nov;3(11):e442. https://doi.org/10.1371/journal.pmed.0030442 PMID:17132052

23. Mathers CD, Fat DM, Inoue M, Rao C, Lopez AD. Counting the dead and what they died from: an assessment of the global status of cause of death data. Bull World Health Organ. 2005 Mar;83(3):171-7. PMID:15798840

24. Wild S, Roglic G, Green A, Sicree R, King H. Global prevalence of diabetes: estimates for the year 2000 and projections for 2030. Diabetes Care. 2004 May;27(5):1047-53. https://doi.org/10.2337/diacare.27.5.1047 PMID:15111519

25. Projections of mortality and causes of death, 2015 and 2030. Geneva: World Health Organization; 2015 (http://www.who.int/ healthinfo/global_burden_disease/projections/en/, accessed 1 March 2018).

26. Odden MC. Coxson PG. Moran A. Lightwood JM. Goldman L. Bibbins-Domingo K. The impact of the aging population on coronary heart disease in the United States. Am J Med. 2011;124(9):827-33. PMID:21722862

27. Poston PL, Micklin M. Handbook of population. New York: Kluwer Academic/Plenum Publishers; 2005

28. Siegel R, Naishadham D, Jemal A. Cancer statistics, 2013. CA Cancer J Clin. 2013;63(1):11-30. doi: 10.3322/caac.21166 PMID:23335087

29. Khosravi A, Aghamohamadi S, Kazemi E. Mortality profile in Iran (30 provinces) in 2011. Tehran: Ministry of Health and Medical Education; 2015 [in Farsi].

30. Annual statistical report. Tehran: Legal Medicine Organization; 2015 [in Farsi]. 